\title{
Failure to establish islet amyloid polypeptide (amylin) as a circulating beta cell inhibiting hormone in man
}

\author{
D.Bretherton-Watt ${ }^{1}$, S. G. Gilbey ${ }^{1}$, M. A. Ghatei ${ }^{1}$, J. Beacham ${ }^{2}$ and S. R. Bloom ${ }^{1}$ \\ Departments of ${ }^{1}$ Medicine and ${ }^{2}$ Chemical Pathology, Royal Postgraduate Medical School, London, UK
}

\begin{abstract}
Summary. The presence of islet amyloid polypeptide in amyloid within pancreatic islet cells in Type 2 (non-insulin-dependent) diabetes, and its reported inhibition of glucose uptake by skeletal muscle in vitro, has prompted speculation concerning its role in the pathogenesis of diabetes. We investigated the effect of infused synthetic amidated human islet amyloid polypeptide (mol. wt. 3904, confirmed by mass spectroscopy) on intravenous glucose tolerance. Seven healthy, non-obese volunteers (age $\pm \mathrm{SD}, 27 \pm 4$ years) were infused over 50 min with normal $(0.9 \%)$ saline or islet amyloid polypeptide at $50 \mathrm{pmol} \cdot \mathrm{kg}^{-1} \cdot \mathrm{min}^{-1}$. After $20 \mathrm{~min}$, a bolus of $0.5 \mathrm{~g} / \mathrm{kg}$ glucose was given within $1 \mathrm{~min}$ and blood sampling continued for up to $60 \mathrm{~min}$. Circulating concentrations of islet amyloid polypeptide reached at steady state were
\end{abstract}

$1130 \pm 90 \mathrm{pmol} / \mathrm{l}$. The calculated half-life was $11.8 \pm 0.9 \mathrm{~min}$, metabolic clearance rate $5.7 \pm 0.6 \mathrm{ml} \cdot \mathrm{kg}^{-1} \cdot \mathrm{min}^{-1}$ and apparent distribution space therefore $94 \pm 12 \mathrm{ml} / \mathrm{kg}$. However, islet amyloid polypeptide was found to have no effect on the peak value reached, or the total area under the curve for plasma glucose, insulin or glucagon following intravenous glucose. This study suggests circulating islet amyloid polypeptide may not be an important influence on intravenous glucose tolerance in man.

Key words: Islet amyloid polypeptide, man, intravenous glucose tolerance test, Type 2 (non-insulin-dependent) diabetes mellitus, radioimmunoassay.
Islet (or insulinoma) amyloid polypeptide (IAPP), or amylin, a 37 amino acid peptide with $46 \%$ homology to calcitonin gene-related peptide (CGRP), has recently been purified from an insulinoma [1] and found to comprise the major component of the pancreatic amyloid deposits of Type 2 (non-insulin-dependent) diabetic patients [2]. IAPP has been co-localised with insulin in the beta cell secretory granule [3]. It opposes the action of insulin on isolated muscle [4] and inhibits insulin release from isolated rat islets in vitro [5].

These findings have prompted speculation concerning the possible role of IAPP in normal physiology and in the pathogenesis of Type 2 diabetes. We therefore investigated the effect of IAPP on the in vivo glucose tolerance in normal human volunteers.

\section{Subjects and methods}

Seven healthy, non-obese and fasting volunteers were studied, 3 male, 4 female, mean \pm SD age $27 \pm 4$ years, body mass index $21.2 \pm 1.6 \mathrm{~kg} / \mathrm{m}^{2}$. The study protocol was approved by the Hammersmith Hospital ethical committee and informed written consent obtained from each subject. Infusions were carried out single-blind and in random order. Subjects received either a control infusion of $0.9 \%$ $\mathrm{NaCl}$ (normal saline) (containing $10 \%$ plasma) or IAPP at a nominal rate of $50 \mathrm{pmol} \cdot \mathrm{kg}^{-1} \cdot \mathrm{min}^{-1}$. At least 7 days was left between each infusion.

Sterile, synthetic, human amidated IAPP (mol.wt. 3904, confirmed by mass spectroscopy, M-Scan Ltd., Silwood Parks, Berks., UK) was purchased from Bachem Inc. (Torrance, Calif., USA) and had $>99 \%$ purity by HPLC. The peptide was dissolved immediately before infusion in normal saline containing the subjects own plasma ( $10 \%$ by volume). After 20 min ("time $0 ") 20 \%$ dextrose $(0.5 \mathrm{~g} / \mathrm{kg}$ ) was given within one min i.v.. The infusion wsa continued for a further $30 \mathrm{~min}$ and blood sampling for up to $60 \mathrm{~min}$ after glucose administration.

Blood samples were collected into appropriate tubes for measurement of glucose, glucagon, insulin and IAPP. After centrifugation, plasma was stored immediately at $-20^{\circ} \mathrm{C}$ until assay. A sample from the infusion line was also taken and frozen for estimation of actual concentration of IAPP administered.

\section{Radioimmunoassay $(R I A)$}

Established RIAs were used to measure plasma concentrations of insulin and glucagon. RIA of IAPP in the plasma samples and infusates was carried out in $0.8 \mathrm{ml} 0.06 \mathrm{~mol} / \mathrm{l}$ phosphate buffer, $\mathrm{pH} 7.4$, containing $10 \mathrm{mmol} / 1 \mathrm{EDTA}, 8 \mathrm{mmol} / 1$ sodium azide, $1.0 \%$ (weight/ volume) bovine serum albumin and $0.02 \%$ polyoxyethylene sodium 

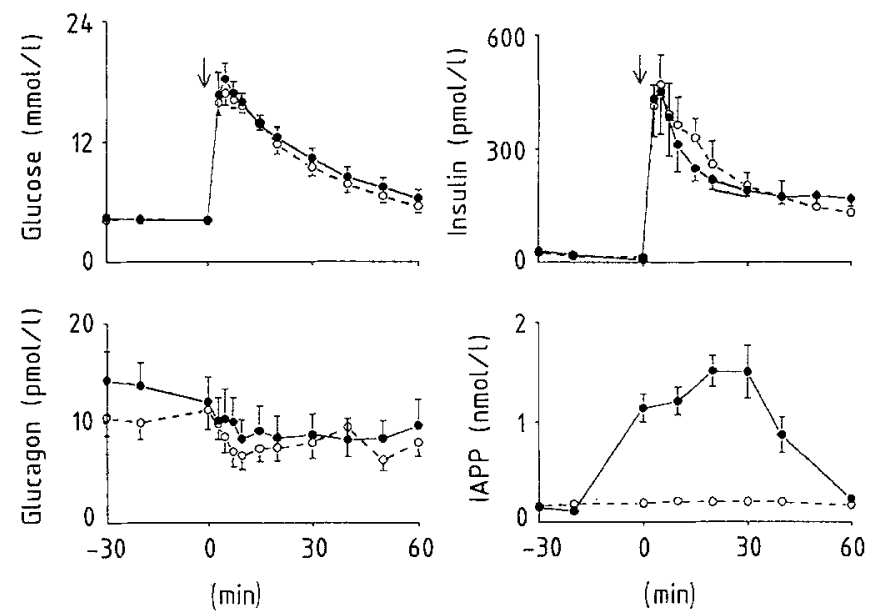

Fig. 1. The concentrations (mean \pm SEM, $n=7$ ) of glucose (top left), insulin (top right), glucagon (bottom left) and islet amyloid polypeptide IAPP (bottom, right) achieved by an i.v. glucose bolus (indicated by arrow) administered (at time $0 \mathrm{~min}$ ) during a $50 \mathrm{~min}$ (from -20 to $+30 \mathrm{~min})$ saline $(0.9 \% \mathrm{NaCl})$ infusion $(\mathrm{O})$ and IAPP infusion (๑) are shown

monolaureate (Tween 20, Sigma Chemical Co., St Louis, Mo., USA). The antibody, raised to human IAPP, was purchased from Peninsula Laboratories (St Helens, Merseyside, UK). IAPP was iodinated using Bolton and Hunter reagent and purified by HPLC. The tracer had a specific activity of $34 \mathrm{~Bq} / \mathrm{fmol}$. The assay standard was synthetic, human amidated IAPP. Samples were incubated with antibody for $24 \mathrm{~h}$ at $4^{\circ} \mathrm{C}$ before addition of tracer $(0.9 \mathrm{fmol} /$ tube $)$ and for a further 3 days before separation of free and antibody-bound peptide by dextran-coated charcoal ( $6 \mathrm{mg} / \mathrm{tube})$. The assay had a detection limit of $5 \mathrm{fmol} /$ assay tube. Inter- and intra-assay variations were less than $10 \%$.

Glucose measurements were carried out on a glucose analyser (RA-1000, Technicon Instruments Co. Ltd., Basingstoke, UK) using Technicon Method No.SM4-014.3185. The assay had a coefficient of variation of $1.2 \%$

\section{Statistical analysis}

Results are expressed as mean \pm SEM. Total areas under the curve (AUCs) were calculated, using parallelogram approximations, and these were then compared using Student's paired $t$-tests. Glucose disappearance rates following the i.v. glucose were expressed in terms of the $\mathrm{K}$ value [6].

\section{Results (Fig. 1)}

There were no adverse reactions to the infusions and no change in blood pressure or pulse rate.

Fasting plasma glucose levels were similar during both infusions. The glucose bolus caused a $4-5$ fold increase in blood sugar within 3-5 min. Calculation of the clearance rate of glucose during the saline infusion gave a $\mathrm{K}$ value of $2.6 \pm 0.3$, mean $\pm \mathrm{SEM}, n=7$, and during IAPP infusion a $\mathrm{K}$ value of $2.4 \pm 0.5$ (normal $\mathrm{K}$ value >1.2). The AUC for the glucose response was also unchanged: saline, AUC $449 \pm 73$; IAPP, AUC $485 \pm 58$.

Plasma insulin rose from a fasting level of $17 \pm 5 \mathrm{pmol} / 1$ to $470 \pm 80 \mathrm{pmol} / \mathrm{l} 5 \mathrm{~min}$ after glucose administration.
During IAPP infusion, insulin rose during the same period from $20 \pm 4$ to $452 \pm 111 \mathrm{pmol} / \mathrm{l}$. The AUC was again unchanged: saline, AUC 11,803 $\pm 1,825$; IAPP, AUC 12,726 $\pm 2,983$.

Pancreatic glucagon was suppressed during the i.v. glucose tolerance test from a fasting concentration of $10.5 \pm 1.8 \mathrm{pmol} / 1$ to $6.7 \pm 1.4$ at $10 \mathrm{~min}$ and during IAPP infusion from $14.3 \pm 2.9$ to $8.4 \pm 1.9 \mathrm{pmol} / \mathrm{l}$. There were no differences in the respective AUC.

IAPP concentrations from the infusion line indicated a peptide loss of $86 \pm 2 \%$, presumably due to peptide aggregation or adsorption onto plastic surfaces. Mean plasma IAPP concentration for the last $30 \mathrm{~min}$ of infusion was $1330 \pm 90 \mathrm{pmol} / \mathrm{l}$. The calculated metabolic clearance rate was $5.7 \pm 0.6 \mathrm{ml} \cdot \mathrm{kg}^{-1} \cdot \min ^{-1}$ and the half-time of decay from the incremental plateau was $11.8 \pm 0.9 \mathrm{~min}$. The apparent distribution space was therefore $94 \pm 12 \mathrm{ml} / \mathrm{kg}$ [7]. Plasma IAPP-like immunoreactivity during the saline infusion was $20 \pm 2 \mathrm{pmol} / \mathrm{l}$, at the detection limit of the assay, and did not rise significantly following i.v. glucose infusion.

\section{Discussion}

Anatomical and experimental evidence has pointed to a possible role for IAPP not only in the regulation of pancreatic beta cell function, but also in the pathogenesis of diabetes. This might be by direct interference with insulin release [5], by contributing to the peripheral insulin resistance which is a prominent feature of Type 2 diabetes [4], or by inducing amyloid production which in turn may impair beta cell function $[1,2]$.

However, IAPP has not yet been shown to have any effect on carbohydrate metabolism in vivo. This study investigated the effect of high dose IAPP on i.v. glucose tolerance in healthy volunteers. Despite considerable losses, circulating plasma concentrations of IAPP in excess of $1 \mathrm{nmol} / \mathrm{l}$ were achieved and yet IAPP had no effect on glucose clearance or glucose-stimulated insulin and pancreatic glucagon responses.

One possible explanation is that biologically inactive amylin was being infused. These infusions were carried out using synthetic human, C-terminal amidated IAPP. This is presumed to be the biologically active moiety [8], although a non-amidated form has been isolated [1]. While we cannot be absolutely certain that the IAPP infused was identical to the native form, animal experiments using this same peptide have shown it to dramatically affect calcium metabolism [9], suggesting biological potency. It is also possible that the 37 amino acid IAPP is not the active form and that alternative intracellular processing may yield more potent forms (as in the case of glucagon-like peptide-1 [10]). However, the same consideration would apply to in vitro studies using synthetic IAPP which have shown bioactivity $[5,9]$.

Our findings do not preclude a role for IAPP as a local modulator of insulin secretion by the beta cell, in a paracrine or autocrine role, which might be of considerable importance in the pathophysiology of diabetes mellitus. However, the lack of any effect of very elevated IAPP lev- 
els on i.v. glucose tolerance in man may indicate that it is unlikely to be acting as a circulating hormone to cause peripheral insulin resistance or influence insulin release.

\section{References}

1. Westermark P, Wernstedt C, Wilander E, Hayden DW, O'Brien TD, Johnson KH (1987) Amyloid fibrils in human insulinoma and islets of Langerhans of the diabetic cat are derived from a neuropeptide-like protein also present in normal cells. Proc Natl Acad Sci USA 84: 3881-3885

2. Cooper GJ, Willis AC, Clark A, Turner RC, Sim RB, Reid KB (1987) Purification and characterisation of a peptide from amyloid-rich pancreases of type-2 diabetic patients. Proc Natl Acad Sci USA 84: 8628-8632

3. Lukinius A, Wilander E, Westermark GT, Engstrom U, Westermark $\mathbf{P}(1989)$ Co-localisation of islet amyloid polypeptide in the $\mathrm{B}$ cell secretory granules of human pancreatic islets. Diabetologia 32: 240-244

4. Cooper GJS, Leighton B, Dimitriadis GD, Parry-Billings M, Kowalchuk JM, Howland K, Rothbard JB, Willis AC, Reid KBM (1988) Amylin found in amyloid deposits in human type 2 diabetes mellitus may be a hormone that regulates glycogen metabolism in skeletal muscle. Proc Natl Acad Sci USA 85: $7763-7766$
5. Ohsawa H, Kanatsuka A, Yamaguchi T, Makino H, Yoshida S (1989) Islet amyloid polypeptide inhibits glucose-stimulated insulin secretion from isolated rat pancreatic islets. Biochem Biophys Res Commun 160: 961-967

6. Lundbaek K (1962) Intravenous glucose tolerance as a tool in definition and diagnosis of diabetes mellitus. Br Med J 2:1507-1513

7. Goldstein A, Aronow L, Kalman SM (1974) Principles of drug action, 2nd edn. John Wiley, New York, p 311

8. Mosselman S, Hoppener JWM, Zandberg J, van Mansfield ADM, Geurts van Kessel AHM, Lips CJM, Jansz HS (1988) Islet amyloid polypeptide: identification and chromosomal localisation of the human gene. FEBS Lett 239:227-232

9. Datta HK, Zaidi M, Wimalawansa SI, Ghatei MA, Beacham JL, Bloom SR, MacIntyre I (1989) In vivo and in vitro effects of amylin and amylin-amide on calcium metabolism in the rabbit. Biochem Biophys Res Commun 162: 876-881

10. Kreymann B, Ghatei MA, Williams G, Bloom SR (1987) Glucagon-like peptide-1 (7-36): a physiological incretin in man. Lancet II: $1300-1303$

Received: 9 October 1989

Prof. S. R. Bloom

$2^{\text {nd }}$ Floor, Francis Fraser Laboratory

Hammersmith Hospital

150 DuCane Road

London W12 ONN

UK 